\title{
INCOME TAX: GROSS INCOME - CAPITAL VERSUS REVENUE, PROFIT-MAKING SCHEME OR FIXED/FLOATING-CAPITAL TEST?
}

\section{Introduction}

The question of whether a receipt or accrual is of a capital nature or not has vexed the courts, legal minds and tax advisors for years. Simplifying or limiting the tests would provide greater certainty.

According to some writers (Clegg "The Intention of the Taxpayer" in Income Tax in South Africa (2006) Ch 5 par 5 2; Emslie, Davis, Hutton and Olivier Income Tax Cases and Materials 3ed (2001); Huxham and Haupt Notes on South African Income Tax 26ed (2007); and Williams Income Tax in South Africa Law and Practice 4ed (2006)), the case of CIR v Pick 'n Pay Employee Share Purchase Trust (1992 4 SA 39 (A), 54 SATC 271, hereinafter "Pick 'n Pay") seems to have finally limited the test in capital/revenue cases to the "profit-making scheme" test.

However, in subsequent cases there is no suggestion that the scheme of profit-making test is the sole test. In Berea Park Avenue Properties (Pty) Ltd $v$ CIR (1995 2 SA 11, 57 SATC 167) it is clear that the Appellate Division (as it then was) considered a profit-making scheme and trading stock in one breath, so to speak.

In SARS v Knuth and Industrial Mouldings (Pty) Ltd (1999 62 SATC 65), a case heard in the Eastern Cape Provincial Division of the High Court dealt with the proceeds of the sale of shares. The case was concerned with the floating versus fixed-capital test, and Leach $\mathrm{J}$ opined (72) that the distinction "is often referred to in tax cases and can now be regarded as entrenched in our law". Leach J referred to Pick 'n Pay, but only to the extent that sound commercial and good sense should prevail in selecting the tests applicable.

It was held in Pick 'n Pay that if there is no trading then there can be no floating capital. The trading stock definition was not considered in the majority judgment.

The profit-making scheme test is only one way of establishing that an asset is trading stock. An asset acquired for the purpose of sale is trading stock and the proceeds are gross income. That should, it is submitted, be the basis on which capital/revenue cases are decided. The scheme of the profit-making test is but one method of establishing intention at acquisition. It is submitted that the intention to make a profit, inherent in the concept of a profit-making scheme, is not essential to establish trading. "Gross income" is 
receipts and accruals, not profits. The majority judgment in this case is, it is submitted, flawed in that it did not consider this reality.

For years the courts have vacillated between the "floating capital/fixed capital" and "profit-making scheme" tests to establish whether the proceeds of the disposal of an asset is of a capital or revenue nature for the purpose of establishing gross income as defined in the Income Tax Act 58 of 1962.

Pick ' $n$ Pay seems to have finally limited the test of whether proceeds are of a capital or revenue nature to the "profit-making scheme" test.

This note questions that submission by examining the concepts and application of the two tests, trading stock, Pick 'n Pay and subsequent capital/revenue cases.

\section{The concepts and their cases}

\section{Scheme of profit-making}

The scheme of profit-making test as encapsulated Pick 'n Pay infers the intention to make a profit on the disposal of an asset. In other cases transactions have been held to have been carried out in a business-like manner in pursuing a profit-making scheme (see, eg, COT $v$ Booysens Estates Limited 1918 AD 576, 32 SATC 10 - profit-making scheme (fixed property); CIR v Stott 1928 AD 252, 3 SATC 253 - minority: profit-making venture (fixed property); CIR v Strathmore Exploration Limited $19561 \mathrm{SA}$ 591 (A), 20 SATC 375 - profit-making scheme (fixed property); SIR $v$ Trust Bank of Africa Ltd 19753 SA 652 (A), 37 SATC 87 - profit-making scheme (sale of shares); CIR v Nedbank Limited 19863 SA 591 (A), 48 SATC 73 profit-making scheme (sale of shares); Pick 'n Pay - profit-making scheme (sale of shares); CIR v Nussbaum 19964 SA 1156 (A), 58 SATC $283-$ profit-making scheme (sale of shares); and CIR v Wyner [2003] 4 All SA 541 (SCA), 66 SATC 1 - profit-making scheme (fixed property)).

\section{Fixed and floating capital}

Fixed capital is understood to be the operating structure used to earn income. The disposal of such assets results in receipts of a capital nature. On the other hand floating capital is used as an income earning asset that is exchanged for money, treated as trading stock, and the receipt is clearly of a revenue nature (see, eg, CIR v Stott supra - fixed and floating capital (fixed property); CIR v Richmond Estates (Pty) Ltd 19561 SA 602 (A), 20 SATC 355 - fixed and floating capital (fixed property); African Life Investment Corporation (Pty) Ltd v SIR 19694 SA 259 (A), 31 SATC 163 - (sale of shares) - active investment policy: refers to CIR v Richmond Estates supra; Barnato Holdings Ltd $v$ SIR 19782 SA 440 (A), 40 SATC 75 - dealing in shares for profit; not fixed capital; profit motive; Bloch $v$ CIR 19802 SA 401 (C), 42 SATC 7 - fixed and floating capital (sale of shares); CIR $v$ Tod 1983 2 SA $364(\mathrm{~N}), 45$ SATC 1 - fixed and floating capital (sale of shares); and 
CSARS v Knuth and Industrial Mouldings (Pty) Limited 62 SATC 65 74-75, 1999 (E) - fixed and floating capital (sale of shares)).

In certain cases the two concepts have been combined. Taxpayers were found to have been carrying on a business or trade, being a scheme of profit-making using the asset as stock-in-trade (see, eg, Natal Estates Ltd $v$ SIR 19754 SA 177 (A), 37 SATC 193 - capital/stock-in-trade used in a scheme of profit-making; Berea West Estates (Pty) Ltd v SIR 19762 SA 614 (A), 38 SATC 43 - using land as stock-in-trade; John Bell \& Co (Pty) Limited $v$ SIR 19764 SA 415 (A), 38 SATC 87 - profit-making scheme using land as stock-in-trade; Barnato Holdings $v$ SIR supra - dealing in shares for profit not fixed capital - profit motive; Elandsheuwel Farming (Edms) Bpk v SBI 19781 SA 101 (A), 39 ATC 163 - carrying on business with property as stock-in-trade; CIR v Malcolmess Properties (Isando) (Pty) Ltd 19992 SA 27 (A), 53 SATC 153 - scheme of profit-making using land as stock-in-trade (fixed property); Berea Park Avenue Properties (Pty) Limited v CIR 19952 SA 411 (AD), 57 SATC 167 - profit-making scheme and stock-in-trade; and CSARS v Van Blerk 20002 SA 1016 (C), 62 SATC 131 - trading in sand stock-in-trade).

\section{$3 \quad$ Trading and trading stock}

Trading stock is defined as ( $\mathrm{s} 1$ of the Income Tax Act)

"anything ... purchased or in any other manner acquired by the taxpayer for the purpose of ... sale or exchange by him or on his behalf ..."

This part of the definition was relevant to the years of assessment 1982 to 1984, the period to which Pick 'n Pay relates.

The intention of the taxpayer coupled with actual operations or activities will signify whether or not the taxpayer is trading. Williams (162), in discussing the concept of "trading" in South African tax law, states that "many judicial decisions have regarded the taxpayer's intention vis-à-vis the property in question as decisive or at least the dominant factor in determining whether his actions amount to trading". In Burgess v CIR Grosskopf JA held that trade as defined "should be given a wide interpretation" and referring to Dowling J (ITC 770), with approval, that it was "obviously intended to embrace every profitable activity and ... should be given the widest possible interpretation".

It has been held that the absence of profit does not necessarily mean that a taxpayer is not trading. There may be good reason for expenditure incurred for the purpose of trade without the expectation of a profit or even requiring a profit (De Beers Holdings (Pty) Ltd v CIR 47 SATC 229 260).

In Pick 'n Pay (280) it was held that a profit-motive is not essential for carrying on a business but that its presence or absence is an important factor in determining whether or not a business is being conducted.

Pick ' $n$ Pay encapsulates the concept of "an operation of business in carrying out a scheme of profit-making" and seems to have endorsed the 
corollary that proceeds "will be non-revenue if they do not derive from an operation of business in carrying out a scheme of profit-making" - see below for a full discussion of this corollary. The dissenting judgment did not endorse this corollary. Nicholas AJA (291) held that this premise could not be supported and that the Special Court erred in drawing the conclusion that because the Trust had showed that the acquisition and resale of the shares were not in pursuance of a scheme of profit-making, the proceeds were not income and were therefore of a capital nature.

In Natal Estates Ltd (supra 203) it was held that "From the totality of facts one enquires whether it can be said that the owner had crossed the Rubicon and gone over to business, or embarked on a scheme, of selling such land for profit, using the land as his stock-in-trade" (Holmes JA's emphasis). It is submitted that in this case the concepts of a profit-making scheme and trading stock were considered as being one and the same.

In SBI v Aveling (40 SATC 1 17-18) it was held that it needs to be clear that the taxpayer had the intention of ceasing to trade with his livestock and to hold and use the livestock as fixed capital in order to alter the character from floating to fixed capital. The taxpayer must have intended to cease trading. This argument was interpreted by Smalberger JA in Pick 'n Pay (283) as meaning that "[w]hen no trade is conducted there cannot be floating capital".

It is submitted that the profit-making scheme and the fixed/floating-capital tests are different sides of the same coin.

Emslie ("Intention, Motive and Profits, the Taxation of Reluctant Profitmakers" 1988 Tax Planning), in discussing the special court judgment of Pick 'n Pay and ITC 1413 discussed the lack of consideration given to the trading stock definition and submitted that "the shares concerned were acquired for the purposes of sale to employees and for this reason fell squarely within the definition of the term "trading stock'" (31).

It is submitted by Emslie that it is difficult to conceive of a situation in which an asset is purchased for resale and is not trading stock.

It is also submitted that in not considering the trading stock definition, the majority of the court in Pick 'n Pay erred and as a result seems to have come to the wrong conclusion.

\section{$4 \quad$ The Pick 'n Pay Employee Shareholder Trust}

Both the majority and minority judgments in Pick ' $n$ Pay agreed that there is no single test for establishing the capital or revenue nature of the income. These sentiments echo almost all the capital/revenue cases of the past.

Smalberger JA, delivering the majority judgment, held at the beginning of his argument (279 of 54 SATC 271) that there are a variety of tests, that they are guidelines, only there being no single infallible test of invariable application. He agreed with Friedman J in ITC 1450 (76) that "one should not 
be led to a result in one's classification of a receipt as income or capital which is ... contrary to sound commercial and good sense".

Nicholas AJA, in delivering the dissenting judgment, held that (288) the tests enunciated in the decided cases are not to be regarded as either prescriptive or comprehensive: they do no more than provide guidelines. Each case must be decided on its own facts.

Both judgments agreed with the special court that "the scheme of the trust did not have the purpose of making a profit". The majority judgment decided the case based on the profit-making scheme test and the consideration of the taxpayer's "object, his aim, his actual purpose", while the minority concluded that the shares were floating capital based on the finding that "the trust engaged in share-dealing activities which were characteristic of a business".

The trust, in this case, was formed to administer the "Pick 'n Pay Stores Limited Employee Share Purchase Scheme" to enable the company to provide its employees and the employees of its subsidiaries, including directors holding salaried employment or office, with the opportunity of acquiring interests in the share capital of the company.

The majority judgment, handed down by Smalberger JA, concluded that the "trustees were not carrying on a business with the contemplation of making profits". And, having concluded that "[o]n a common sense approach the Trust was not carrying on a business by trading in shares" (280), the income was of a capital nature.

Having said that the variety of tests were guidelines only, Smalberger JA continued by saying that the receipts accruing to the trust would be revenue if they constitute "a gain made by an operation of business in carrying out a scheme for profit-making".

It seems that he is considering all capital/revenue cases, not only those involving shares, as he says, later in this same paragraph that "Transactions involving shares do not differ from transactions in respect of any other property and the capital or revenue nature of a receipt is determined in the same way whether one is dealing with land or shares". He held that they will be non-revenue if they do not derive from "an operation of business in carrying out a scheme for profit-making" (280). He accepted that a series of transactions is characteristic of the carrying on of a business (Nicholas AJA's argument in the minority judgment), but that whether the receipts were revenue still depended on whether the business was conducted with a profitmaking purpose. "To hold otherwise would amount to a departure from the earlier authorities - something clearly never intended in either the Natal Estates or Elandsheuwel Farming cases ..." These cases held that "receipts or accruals bear the imprint of revenue if they are not fortuitous, but designedly sought for and worked for ..."

The majority judgment is based on the finding that the trust had no intention of conducting a business. It did not operate along business lines. "On a common sense approach the Trust was not carrying on a business by 
trading in shares ... the trustees never intended or designedly set out to make a profit - it was not their purpose to do so."

It must be noted, however, that trade as defined makes no mention of a profit motive and trading stock includes anything acquired for resale.

It is submitted that the crux of the decision lies in the conclusion that the Trust's receipts were fortuitous (281). Smalberger JA took the view that the receipts were not intentional or worked for, but purely fortuitous in the sense of being an incidental by-product. They were therefore non-revenue.

It is interesting to note that at no time was the definition of trading stock considered in the majority judgment.

The minority judgment, handed down by Nicholas AJA, also considered the profit-making scheme test. Nicholas AJA then went on to discuss the various tests relating to deductions under section $11(\mathrm{a})$, referring to cases and the fixed and floating capital distinction raised in Commissioner for Inland Revenue v George Forest Timber Co Ltd (1924 AD 516 289) and various other cases. It should be noted that all these cases dealt with expenditure issues, not proceeds, although in a case such as Pick 'n Pay these issues are, it is submitted, relevant. Nicholas AJA was arguing that the trust was in fact trading.

He then referred to Elandsheuwel Farming (Edms) Bpk (supra) and specifically to the statement in that case that the "enquiry as to whether the sale amounted to the realisation of a capital asset or whether it was the sale of an asset in the course of carrying on a business or in pursuance of a profit-making scheme. Where a single transaction is involved it is usually more appropriate to limit the enquiry to the simple alternatives of a capital realisation or a profit-making scheme. In its normal and most straightforward form, the latter connotes the acquisition of an asset for the purpose of reselling it at a profit. ... The asset constitutes in effect the taxpayer's stockin-trade or floating capital" (author's emphasis).

In referring to Natal Estates Ltd (supra) he mentioned the consistent distinction drawn by the Appellate Division between realising a capital asset "and selling an asset in the course of carrying on a business or embarking on a scheme for profit".

It is submitted that this analysis by Nicholas AJA uses the fixed/floating capital argument and scheme of profit-making as an overall argument to establish trading, or the carrying on of a business, which concept is included in the definition of "trade" in the Income Tax Act. There is really no distinction as to a single part being the most important.

In discussing the application of the law to the facts (294 et seq), Nicholas AJA points out that the trust has no income-earning structure and that there was no evidence that the Trust held the shares as a permanent investment. They were therefore floating capital. Nicholas AJA agrees "with the Special Court that the scheme of the Trust did not have the purpose of making a profit". This was also referred to in the majority judgment. 
In the following paragraph Nicholas AJA argues that the fact that a scheme of profit-making results in proceeds of a revenue nature does not mean that if it is not such a scheme, that the proceeds are automatically not of a revenue nature (see above for Smalberger JA's statement).

The ratio decidendi of the minority judgment is contained in the final paragraph (297), where it was said that although the trust did not carry on a business as the word is ordinarily understood and that a profit motive was not the driving force, the trust was not engaged in realising investments, but was trading in shares. "The essential idea underlying trade is buying and selling" (per Wessels $\mathrm{J}$ in the court a quo in Western Deep Levels $v$ Feinstein supra 290.) The receipts from such trading had all the attributes of income: they were produced by the capital of the trust; they were recurrent; and they were not fortuitous in any relevant sense."

To this Smalberger JA could not agree (282 et seq) and agreed with the minority judgment's conclusion that the shares were floating capital. He points out that because the Pick 'n Pay group could not lawfully assist employees to purchase shares in any company of the group the Trust was formed to do so and acted as the group's alter ego and that the purpose of the scheme was not one of profit-making.

He goes on to say:

"That notwithstanding, Nicholas AJA holds that the shares acquired by the Trust constituted floating capital. In my opinion, an analysis of the manner in which the Trust held and dealt with the shares makes that conclusion untenable. For the reasons already advanced, it was not the intention (purpose) of Stores or the trustees that the Trust should carry on business by trading in shares for profit. That conclusion, with respect, effectively disposes of the finding by Nicholas AJA that the unsold shares held by the Trust from time to time constituted floating capital" (283).

It is submitted that the above does not dispose of the floating capital argument effectively. It in effect reiterates that if the purpose is not profitmaking then the proceeds must be of a capital nature, which was the basis on which the majority judgment was formed.

The sentence immediately following the above, "Where no trade is conducted there cannot be floating capital (see Sekretaris van Binnelandse Inkomste $v$ Aveling $19781 \mathrm{SA}$ 862(A) 880B-881A)", is the part of the judgment that writers and commentators have homed in on and now argue, effectively disposes of the fixed/floating-capital test.

\section{Subsequent cases}

Huxham and Haupt (supra) are of the opinion that Pick 'n Pay established the principle that things acquired otherwise than in a scheme of profitmaking are capital. In order to discharge the onus of demonstrating that an asset is of a capital nature a taxpayer will merely have to satisfy the court that he was not engaged in a scheme of profit-making. This means that even in the case of an asset bought for the purpose of immediate resale the 
proceeds will be of capital nature as long as there is no scheme of profitmaking.

With respect, it is submitted that this conclusion is in conflict with the trading-stock definition and does not take into account that it is but one of several tests to be considered (as noted by both judges in that case).

In CSARS v Wyner ([2003] 4 All SA 541 (SCA), 66 SATC 1, 14), Southwood AJA held that "[a] distinction must be drawn between the making of the discounted offer, which clearly was fortuitous, and the acquisition of the property for resale, which was anything but fortuitous" (author's emphasis).

If an asset is acquired for the purpose of resale the proceeds will be of a revenue nature. It cannot be fixed capital. It must be trading stock. It falls squarely within the trading-stock definition.

Emslie et al (180) state that "the consistently applied test for distinguishing between capital and revenue receipts or accruals, confirmed in Pick 'n Pay (85), is the inquiry whether a taxpayer is engaged in a "scheme of profitmaking". This means that receipts or accruals bear the imprint of revenue if they are not fortuitous, but designedly sought for and worked for. Even where a business is carried on, receipts and accruals will only be of a revenue nature if the business was conducted with a profit-making purpose, that is, as part of a profit-making venture or scheme. The inquiry is concerned with the taxpayer's "object, his aim, his actual purpose", and not with what might have been contemplated or foreseen. The only exception to this is if the making of profits was inevitable. Furthermore, where no trade is conducted there cannot be floating capital or trading stock" (Pick 'n Pay 85).

It is of interest to note that no criticism is raised regarding the tradingstock definition (see above for a discussion of Emslie's article in 1988).

Clegg, in discussing the fixed versus floating-capital test in relation to intention and Pick 'n Pay, states that "The case has now clearly established that in the absence of a 'scheme of profit-making', receipts and accruals from the disposal of assets must be regarded as of a capital nature" (see also CSARS v Knuth and Industrial Mouldings (Pty) Ltd 20001 SA 1088 (E), 62 SATC 65).

Silke on South African Income Tax (2006), referring to Pick 'n Pay, simply says that "there are exceptions to the rule that an asset must have been acquired for the purpose of resale at a profit before the proceeds derived from its sale may be included in gross income". It is interesting to note that Silke does not emphatically state that the profit-making scheme is the only test. In fact, in discussing the "other factors" in Chapter 3, regarding capital/revenue receipts and accruals, he ends by referring to the statement that there are a variety of factors to be considered and that they are but guidelines.

Jooste ("Planning for the Disposal of an Asset" 1993 Tax Planning 7) is of the opinion that "It is clear from Pick ' $n$ Pay that what is meant by 'intention' 
referred to by Wessels JA in Stott's, case is the purpose or motive with which the asset in question is acquired".

This argument does not take into account the difference in law of the concept of "motive" and "intention". In ITC 1418 (1986 49 SATC 42) Conradie $\mathrm{J}$ said that a taxpayer may have several motives for purchasing a property, but his intention is something to be inferred from his acts and from his dealings with the property.

It seems that not only are the various tax commentators not in agreement, but the courts also.

Berea Park Avenue Properties (Pty) Ltd $v$ CIR is an Appellate Division case that dealt with the profits realised from the sale of a block of flats under sectional title. Nestadt JA (171 of 57 SATC 167) said that the intention of acquisition of property and the circumstances in which it is sold are of decisive importance. He then said, in considering the intention of acquisition that there may be a change of intention "in the sense not merely of a decision to realise the asset (to best advantage) but by the adoption of a new policy which has the effect of converting the character of the asset to trading stock in a profit-making scheme or business (Elandsheuwel Farming (Edms) Bpk v Sekretaris van Binnelandse Inkomste 19781 SA 101(A) 118F119 in fin). The Berea Park case facts are clearly distinguishable from those in Pick 'n Pay and at no stage is Pick 'n Pay referred to during this judgment. However, it is submitted that in the paragraphs above the Appellate Division (now the Supreme Court of Appeal) considers a profit-making scheme and trading stock in one breath, so to speak. There is no suggestion that the consideration of a profit-making scheme is the sole test.

In CSARS v Knuth and Industrial Mouldings (Pty) Ltd (62 SATC 65), a case heard in 1999 in the Eastern Cape Provincial Division of the High Court dealt with the proceeds on the sale of shares. In this case Leach $\mathrm{J}$, in delivering the court's judgment, having laid out the facts of the case, one of which, incidentally, was the prohibition by the Companies Act of providing assistance for the purpose of acquiring its own shares (shades of Pick ' $n$ Pay 70), commenced saying that "various guidelines have been laid down which assist in the determination of the nature of a receipt or accrual". Leach $J$ (72) said that "the difference between fixed and floating capital is not a distinction expressly mentioned in the Act [but] it is often referred to in tax cases and can now be regarded as entrenched in our law ... It is therefore clearly established that an asset held by a taxpayer, either in a nonproductive state or in order to derive income from the productive use thereof, constitutes fixed capital and the proceeds derived from a realisation thereof are of a capital nature. Where an asset is acquired for reselling at a profit, it effectively constitutes the taxpayer's stock-in-trade or 'floating capital' and the proceeds derived therefrom are of a revenue nature ..." Of course, these various "tests" are no more than guidelines and, ultimately, one is called upon to make a decision which is not contrary to sound commercial and good sense - cf Commissioner for Inland Revenue v Pick 'n Pay Employee Share Purchase Trust (1992 4 SA 39 (A) 56H-I) (author's emphasis). The 
reference to Pick 'n Pay was only to the extent that sound commercial and good sense should prevail in selecting the tests applicable.

The Commissioner in this case relied on the profit-making scheme test. Leach $\mathrm{J}$ does not distinguish between a profit-making scheme and floating capital. Throughout this case, it is submitted, he considers floating capital as being used in a scheme of profit-making and, where there is no such scheme, the asset is fixed capital.

There is, it is submitted, no confusion here. Leach $\mathrm{J}(75)$ said that "a taxpayer may change the intention with which he is holding an asset, and that an asset initially held as fixed capital may subsequently be used in a profit-making scheme ... What we are called upon to decide is whether Knuth changed the intention with which he held his share in Oldco in such a way as to render it part of his floating capital". He concluded (76) that "Knuth's sale of his shares in Oldco was not part of a profit-making scheme and that the accrual derived therefrom was therefore derived from the sale of his fixed capital and is not subject to tax".

The discussion is clearly based on the premise that, if the asset is not part of a profit-making scheme, the asset is fixed capital.

\section{Conclusion}

It is submitted that Pick 'n Pay has not established that the profit-making scheme test is the only appropriate test in capital/revenue cases, to the exclusion of the fixed/floating-capital test. Subsequent cases have continued to consider the fixed or floating nature of an asset when considering the taxpayer's disposal thereof.

It is submitted further that the corollary that, if not a profit-making scheme then capital, espoused by the majority in Pick 'n Pay, is flawed and is therefore not being followed. If it can be shown that an asset is and remains fixed capital, the proceeds will be of a capital nature. If it is floating capital it is trading stock.

The two tests have, in my opinion, been refined and brought closer together. The fixed/floating-capital test is used primarily to establish whether a taxpayer is trading. The profit-making scheme test may not always be appropriate for this purpose since the objective of making a profit is not essential to the concept of trade for income tax purposes.

Silke on South African Income Tax submits that "in appropriate circumstances a taxpayer will be carrying on a trade even if he has no objective to make a "profit" or even if he deliberately sets out to make a loss ... But the absence of such an objective or of the prospect of making profits might indicate, along with other factors, that he contemplated purposes other than trade or was not exclusively concerned with trade" (author's emphasis).

Trading stock, floating capital and stock-in-trade are used interchangeably in the cases. The terms all mean the same thing. 
The profit-making scheme test is only one way of establishing that an asset is trading stock. It is submitted that in order to be trading stock the taxpayer must be trading. The cost of trading stock is deductible under section 11(a) of the Income Tax Act. Inherent in the section is the trade requirement. The acquisition of an asset for the purpose of resale makes the asset trading stock. Establishing a taxpayer's intention at acquisition and the subsequent treatment of an asset effectively establishes whether the asset is trading stock. In Pick 'n Pay the shares were acquired for resale in the broadest sense. It is submitted that the majority judgment erred in not considering the trading stock definition.

The profit-making scheme test is useful to establish whether or not a taxpayer is trading. The fixed/floating-capital test is similarly used to establish trading. It is submitted that the two tests continue to be appropriate, but should be considered with the definition of trading stock.

It may be appropriate to ask, in capital/revenue cases, whether the taxpayer's intention is to use the asset as trading stock, rather than whether a scheme is one of profit-making. If the intention was to acquire an asset for resale it is trading stock and proceeds are gross income.

David Joubert

Nelson Mandela Metropolitan University, Port Elizabeth 